\title{
SOME CHARACTERISTICS OF THE SYSTEMATIZATION OF JOINT INTERNATIONAL PROGRAMMES IN HIGHER EDUCATION
}

\author{
ALGUMAS CARACTERÍSTICAS DA SISTEMATIZAÇÃO DE PROGRAMAS \\ INTERNACIONAIS CONJUNTOS DE ENSINO SUPERIOR
}

\author{
ALGUNAS CARACTERÍSTICAS DE LA SISTEMATIZACIÓN DE PROGRAMAS \\ INTERNACIONALES CONJUNTOS DE EDUCACIÓN SUPERIOR
}

\author{
Ilnar Damirovich NIZAMOV ${ }^{1}$ \\ Ramis Rafagatovich NASIBULLOV ${ }^{2}$ \\ Olga Nikolaevna OLEYNIKOVA ${ }^{3}$ \\ Alexander Ivanovich GORYLEV ${ }^{4}$
}

\begin{abstract}
This article discusses the issue of systematization of international joint programmes in higher education. The authors analyze the criteria for differentiating between various types of international joint programmes. In particular, the authors propose to distinguish between international double degree programmes and dual degree programmes. Different classifications of international joint programmes are substantiated through the analysis of successful experience of their implementation in Russia and abroad, in the context of globalization and international educational integration. The article also gives ground to the general criteria of the effectiveness of the implementation of various types of joint educational programmes. It is concluded that the systematization of international joint programmes will allow to avoid confusing terminology, and considering the fact that such programmes are developed and implemented by universities with different backgrounds from different regions of the world, sometimes even from different education systems, this approach will greatly simplify academic cooperation between universities of different countries, in the context of cultural differences and particular features of different national legislative regulations. Considering the different types of joint international programmes and the practice of their implementation in universities, the authors proceed from the fact that all these programmes represent effective ways of creating a single European higher education area, an important tool for implementing the principles of the Bologna process. Regarding the task of improving the competitiveness of universities that implement international joint programmes, the article also identifies the significant benefits for students acquiring specific intercultural,
\end{abstract}

\footnotetext{
1 Kazan Federal University (KPFU), Kazan - Russia. Associate Professor of the Department of Chemical Education. Candidate of Chemical Sciences. ORCID: https://orcid.org/0000-0002-8243-3533. E-mail: nizamilnar@yandex.ru

${ }^{2}$ Kazan Federal University (KPFU), Kazan - Russia. Associate Professor of the Department of Training and Education Methodology, Institute of Psychology and Education. Candidate of Pedagogy. ORCID: https://orcid.org/0000-0002-0382-3235. E-mail: nasibullov_ramis@mail.ru

${ }^{3}$ The National Erasmus+ Office in Russia, Moscow - Russia. Professor and Director of the ANO Center for the Study of Vocational Education Problems, National Office of the Erasmus+ Program in Russia, Centre for VET Studies. Doctor of Pedagogy. ORCID: https://orcid.org/0000-0002-7645-4733. E-mail: onoleynikova@yandex.ru

${ }^{4}$ Nizhny Novgorod State University (UNN), Nizhny Novgorod - Russia. Associate Professor, Head of the Department of European and International Law and Head of the Center for International Projects and Programs. Candidate of Legal Sciences. ORCID: https://orcid.org/0000-0002-9592-0605. E-mail: gorylev@yandex.ru
} 
communicative, as well as interdisciplinary professional competencies and, respectively, advantages in employment, both in their own country and abroad.

KEYWORDS: Joint international programmes. Dual degree programmes. Consecutive degree programmes. Internationalization of education. Interdisciplinarity.

RESUMO: Este artigo discute a questão da sistematização de programas conjuntos internacionais no ensino superior. Os autores analisam os critérios de diferenciação entre os vários tipos de programas conjuntos internacionais. Em particular, os autores propõem a distinção entre programas internacionais de diploma conjunto e programas de diploma duplo. Diferentes classificações de programas conjuntos internacionais são substanciadas através da análise da experiência bem-sucedida de sua implementação na Rússia e no exterior, no contexto da globalização e da integração educacional internacional. $O$ artigo também dá base aos critérios gerais da eficácia da implementação de vários tipos de programas educacionais conjuntos. Conclui-se que a sistematização de programas conjuntos internacionais permitirá evitar a confusão terminológica, e considerando o fato de que tais programas são desenvolvidos e implementados por universidades com diferentes origens de diferentes regiões do mundo, às vezes até mesmo de diferentes sistemas educacionais, esta abordagem simplificará muito a cooperação acadêmica entre universidades de diferentes países no contexto de diferenças culturais e características particulares de diferentes regulamentações legislativas nacionais. Considerando os diferentes tipos de programas internacionais conjuntos e a prática de sua implementação nas universidades, os autores procedem do fato de que todos esses programas representam formas eficazes de criar um único espaço europeu de ensino superior, uma ferramenta importante para a implementação dos princípios do processo de Bolonha. Quanto à tarefa de melhorar a competitividade das universidades que implementam programas conjuntos internacionais, o artigo também identifica os beneficios significativos para os estudantes que adquirem competências profissionais especificas interculturais, comunicativas, bem como interdisciplinares e, respectivamente, vantagens no emprego, tanto em seu próprio país como no exterior.

PALAVRAS-CHAVE: Programas internacionais conjuntos. Programas de graduação dupla. Programas de graduação consecutiva. Internacionalização da educação. Interdisciplinaridade.

RESUMEN: En este artículo se analiza el tema de la sistematización de los programas conjuntos internacionales en educación superior. Los autores analizan los criterios para diferenciar varios tipos de programas conjuntos internacionales. En particular, los autores proponen distinguir entre programas internacionales de doble titulación y programas de doble titulación. Las diferentes clasificaciones de los programas conjuntos internacionales se fundamentan mediante el análisis de la experiencia exitosa de su implementación en Rusia y en el extranjero en el contexto de la globalización y la integración educativa internacional. El artículo también da terreno a los criterios generales de la efectividad de la implementación de varios tipos de programas educativos conjuntos. Se concluye que la sistematización de programas conjuntos internacionales permitirá evitar confusiones terminológicas, y considerando que dichos programas son desarrollados e implementados por universidades con diferentes antecedentes de diferentes regiones del mundo, a veces incluso de diferentes sistemas educativos, este enfoque será muy importante. simplificar la cooperación académica entre universidades de diferentes países en el contexto de las

RPGE- Revista on line de Política e Gestão Educacional, Araraquara, v. 25, n. esp. 1, p. 567-576, mar. 2021. e-ISSN:1519-9029 
diferencias culturales y las características particulares de las diferentes regulaciones legislativas nacionales. Considerando los diferentes tipos de programas internacionales conjuntos y la práctica de su implementación en las universidades, los autores parten del hecho de que todos estos programas representan formas efectivas de crear un único espacio europeo de educación superior, una herramienta importante para implementar los principios del proceso de Bolonia. En cuanto a la tarea de mejorar la competitividad de las universidades que implementan programas conjuntos internacionales, el artículo también identifica los importantes beneficios para los estudiantes que adquieren competencias profesionales especificas interculturales, comunicativas, asi como interdisciplinarias $y$, respectivamente, ventajas en el empleo, tanto en su propio país como en extranjero.

PALABRAS CLAVE: Programas internacionales conjuntos. Programas de doble titulación. Titulaciones consecutivas. Internacionalización de la educación. Interdisciplinariedad.

\section{Introduction}

Education as a social subsystem reflects all the processes and tendencies of the development of society. The new determining characteristics of the modern history is the globalization of the economy, acceleration of the pace of technological change, rapid growth and development of information and communication technologies, and the rethinking of the role of knowledge in society. These trends are clearly manifested in higher education, which is inextricably linked with the formation of intellectual and human capital for the knowledge society. It is a well-known fact that cultural globalization does not entail reproduction of uniformity and homogenization of semantic systems and systems of expression, but involves intensifying the processes of convergence and borrowing and using foreign experience and examples of best practice in the interests of personal development. Such trends are becoming more visible in the system of higher education. This also explains the notable increase in the number of joint educational programmes implemented by universities from different countries. They demonstrate an increasingly important role in the modern landscape of higher education. The types of such programmes are characterized by excessive uniqueness and specificity, which, to some extent, complicates their systematization and analysis (OLEYNIKOVA, 2014).

\section{Methodology}

Within the framework of this article, the authors use methods of comparative analysis of different types of international joint programmes. Based on the identification of specific features of the implementation of such programmes, we propose various methods of their 
classification; as well introduce a uniform terminology for the description of international joint programmes. The analysis of successful experience of implementing these programmes in Russian and foreign universities demonstrated in the article allows to optimize various ways of creating international joint programmes, to show their attractiveness for both students and employers.

In this article, based on the analysis of graduate employment of graduates, who studied at the Lobachevsky University under joint programmes, we demonstrate the unique opportunities for obtaining new professional experience and transnational/international competencies. Participants of international joint programmes have obvious advantages in terms of employment; their competitiveness in the labor market is beyond any doubt.

\section{Results}

For what purposes do universities from different countries need to develop and implement international joint programmes? First, joint programmes are considered through the prism of the internationalization of higher education. They are designed to increase the international prestige of the university, its recognition in the international academic community in the market of educational services, which can also attract foreign students. In many universities, international joint programmes are viewed as a natural extension of exchange and mobility programmes. We can fully agree with the assessments of leading Russian experts that "the formation of joint programmes is not undertaken at random and is not a simple execution of the necessary algorithm. This is part of the university development strategy in terms of international cooperation". On the other hand, the implementation of such programmes should be considered as an opportunity to improve the quality of education and create new employment opportunities for graduates.

It should be noted that there is no uniform terminology for describing international joint programmes. For example, the European University Association (EUA), which periodically organizes studies of the implementation of international joint programmes with the participation of European universities, recorded their significant growth in 2002 (TAUCH; RAUHVARGERS, 2002). But even in these studies, the term "joint degree" includes both joint and dual degrees.

Most often scolars divide joint internationalprogrammes into: 1) joint degree programmes and 2) dual (multiple) degreeprogrammes. 
In the opinion of many foreign scholars, a distinctive feature of the joint (multiple) degree programmes and dual (multiple) degreeprogrammes is the terms (periods) of training of students (KNIGHT, 2011).

Joint degree programmes are less common, in part because of legislative barriers. Legislation in many countries often does not allow universities to award joint qualifications. For example, in Russia, universities issue state-recognized diplomas that do not allow to reflect the names of several universities in them. This does not mean that in our country there are no examples of successfully implemented international joint degree programmes. For example, there is a joint master programme "International Business and Entrepreneurship", implemented by Lobachevsky University (Nizhny Novgorod) and Nottingham Trent University (United Kingdom $)^{5}$. In order to circumvent legal restrictions, partner universities issue a joint non-state diploma to students, who successfully complete the programme. This diploma provides basic information about the programme and the names of cooperating universities. In addition, Russian students receive an official state diploma of Lobachevsky University. Unfortunately, the Lisbon Convention on the Recognition of Credits ${ }^{6}$, which allows for the recognition of a joint degree from two universities, cannot compensate for the lack of such a possibility in national legislation. Without amendments to the legislation in our country, a joint diploma will never become an official document recognized by employers.

Along with joint degree and dual (multiple) degree programmes, Western scholars distinguish programmes of consecutive degrees. Within the framework of these programmes, "students are awarded two different qualifications at consecutive levels after fulfilling the requirements of a joint programme established by partner universities" (ASGARY, 2013).

The latter kind of programmes is gaining increasing popularity in the West. A classic example of such an arrangement is a three-diploma programme "International Bachelor in Information Management - (IBIM)" (RUSSELL; DOLNICAR; AYOUB, 2008). The Programme is implemented by Tilburg University (Netherlands), University of Deusto (Spain), and Bentley University (USA). This programme is the only available instance of cooperation of EU and US universities withing joint traning of students, where students receive three diplomas of partner-universities. Students, who successfully graduate from the programme, get an opportunity to become "hybrid" managers, possessing unique knowledge and skills in the field of information technology and in the field of management of international business. Students have to complete training at all three universities, with

${ }^{5}$ Available: http://www.iee.unn.ru/files/2016/10/buklet-dlya-sajta.pdf. Access: 10 dec. 2020.

${ }^{6}$ Available: http://www.russianenic.ru/int/lisbon/index.html. Access: 10 dec. 2020. 
mobility in partner universities being carried out during the second and third years of study. For example, after analyzing the results of the first year of training of students from the University of Bentley at the University of Deusto, despite the intensity of the curriculum, the programme developers had to adjust it by adding additional disciplines in the Spanish language to the curriculum of the "University of Deusto" (MUKHAMETZYANOVA; TREGUBOVA; KAMALEEVA, 2017; GORYLEV; KUZNETSOVA, 2017).

This type of programmes has a huge potential for interdisciplinary education. They can be implemented both internationally and nationally. In this regard, there is an interesting example from the practice of Australian universities, which provide their students with ample opportunities to obtain two degrees in different fields within a single university.

The presence of a large number of such programmes in Australian universities is due to the fact that Australlian students have an opportunity to freely enroll in academic disciplines in various specialties at different faculties. As a result, students can choose their own disciplines and get two degrees in a variety of fields, for example, computer science and law; art and commerce; trade and engineering; art and computer science, etc. A survey of students participating in these programmes, conducted at the University of Wollongong (UoW), Australia, shows that about $75 \%$ of such students choose a combination of degrees to improve, above all, their employment prospects and acquire new skills. $72 \%$ to $60 \%$ of students from different faculties noted problems with schedules during training in two fields. Thus, universities make a significant contribution to the development of interdisciplinary education, fostering the formation of interdisciplinary skills of students. A number of students in Australia studying simultaneously in two fields has been constantly increasing and in recent years has been approaching to 10\% (MASLENNIKOVA et al., 2017; KOSMODEMYANSKAYA; NIZAMOV; YARULLIN, 2017).

At the national level, Russian universities have also accumulated experience in implementing dual degree programmes. One example of such a programme is a unique educational project - a dual degree programme, which has been implemented since 1995 on the basis of the Faculty of Law and the Institute of Economics and Entrepreneurship of Lobachevsky University (Nizhny Novgorod), on the one hand, and the Faculty of Translation of the Linguistic University of Nizhny Novgorod (LUNN), on the other hand. Since 2014, the programme is implemented as a dual degree programme in Economics - Law - Linguistics (ELL) and provides bachelor level training of lawyers or economists, who can speak two European languages (French and English). At the end of their studies, the students receive two 
diplomas of higher education: a diploma in Law or Economics from Lobachevsky University and a diploma in Interpreting and Translation from LUNN.

This programme is a unique example of an interdisciplinary approach to teaching students based on two Russian universities. It allows students to combine fundamental legal or economic education and professional language training. Students enrolled in the programme simultaneously become the students of Lobachevsky University and LUNN. A particular feature of the programme is that it does not have an integrated curriculum. Students should fully master existing training programmes both at Lobachevsky University and at LUNN. There is quite a number of similarities with dual-diploma programmes at Australian universities. The need to master two degree programmes doubles the academic load of students, forcing the partner-universities to create a special training schedule for them. The students participating in the programme study three days a week at Lobachevsky University and three days a week at LUNN.

The main motivation for students to participate in the programme is employment and career prospects. Competencies of a lawyer or an economist and an interpreter allow the graduates of the programme to have an opportunity to work not only in Russia, but also abroad. Since the launch of the programme, about 300 lawyers-interpreters and about 250 economists-interpreters have graduates from this programme. Practice has shown the relevance of these specialists in the labor market not only in our country but abroad as well. Currently, graduates of the programme, who have a high level of linguistic training (NASIBULLOVA; SALAKHOVA, 2016), successfully work in the structures of the Ministry of Foreign Affairs of the Russian Federation, the Secretariat of the European Court of Human Rights, the Committee of Ministers of the Council of Europe, the Association of European Businesses, the University of Tilburg (the Netherlands), the University of Grenoble Alps (France).

A positive aspect of implementation of the dual-degree programme Economics - Law Linguistics (ELL) was also the creation and implementation of the international Master's dualdegree programme in International and European Law delivered jointly by the Faculty of Law of Lobachevsky University and the Faculty of Law of the University of Grenoble Alpes (France) (MASLENNIKOVA; TREGUBOVA; KHUZIAKHMETOV, 2017). A significant majority of students, who successfully complete the ELL programme, continue their studies in the Master's dual degree programme.

Thus, we consider it expedient to distinguish between international joint degree programmes and dual degree programmes. An analysis of the above examples of 
implementation of joint programmes has made it possible to systematize some of their characteristics and specific features that serve as the basis for their differentiation presented in table 1.

Table 1 - International joint degree programmes and dual degree programmes

\begin{tabular}{|l|l|}
\hline Joint degree programmes & Dual degree programmes \\
\hline $\begin{array}{l}\text { Students study at several universities within the same } \\
\text { field. The main advantage is the acquisition by } \\
\text { students of intercultural competences and additional } \\
\text { skills in connection with the institutional differences } \\
\text { in the teaching in different universities. }\end{array}$ & $\begin{array}{l}\text { Students study at several universities in different fields. } \\
\text { The main advantage is the implementation of the } \\
\text { concept of interdisciplinary education and the } \\
\text { achievement of relevant competencies. }\end{array}$ \\
\hline $\begin{array}{l}\text { The period of study may increase because the } \\
\text { students have to follow mandatory administrative } \\
\text { procedures at partner universities established by } \\
\text { legislation of different countries. }\end{array}$ & $\begin{array}{l}\text { The intensity of training or its duration may sharply } \\
\text { increase in connection with the need for compulsory } \\
\text { mastering by students of unrelated disciplines in various } \\
\text { fields. However, the workload is certainly less than } \\
\text { with training in two separate programmes. }\end{array}$ \\
\hline $\begin{array}{l}\text { Deeply integrated curricula of universities } \\
\text { participating in the programme. The need for a a } \\
\text { sufficiently large degree of coherence of the content } \\
\text { of the main educational modules within the } \\
\text { programme. }\end{array}$ & $\begin{array}{l}\text { The curricula are agreed, but not integrated. Students } \\
\text { are trained at partner universities in curricula in } \\
\text { different fields under coordinated schedules of training. }\end{array}$ \\
$\begin{array}{l}\text { Innovation of such programmes is viewed through a } \\
\text { prism of integration of the complementarity of several } \\
\text { systems and the experience of training in universities } \\
\text { from different countries. }\end{array}$ & $\begin{array}{l}\text { Innovation is viewed through the acquisition of specific } \\
\text { skills and interdisciplinary competencies by students, } \\
\text { which dramatically expand employment opportunities } \\
\text { for graduates. }\end{array}$ \\
\hline
\end{tabular}

Source: Prepared by the authors

\section{Conclusion}

In our opinion, in the nearest future, the academic community should conduct a comprehensive discussion of the development of common terminological approaches to various types of international joint programmes. A uniform approach to the definition of varieties of international joint programmes should be seen as a natural step in the process of building the European Higher Education Area.

ACKNOWLEDGEMENTS: The work is performed according to the Russian Government Program of Competitive Growth of Kazan Federal University.

\section{REFERENCES}

ASGARY, N. Patricia foster benefits and challenges of dual degree programmes: case of EU and the United States. 2013. Available:

https://www.joiman.eu/ProjectResults/PublicDeliverables/Papers/MASTER_Benefits\%20and 
\%20Challenges\%20of\%20Dual\%20Degree\%20Programmes_Case\%20of\%20EU\%20and\%20 United\%20States_Asgary-Foster.pdf. Access: 10 dec. 2020.

GORYLEV, A. I.; KUZNETSOVA, S. N. Joint educational programmes as an instrument of internationalization (the example of the Faculty of Law of Lobachevsky University). Bulletin of the Lobachevsky State University of Nizhny Novgorod.Series: SocialSciences, v. 1, n. 45, p. 150-155, 2017.

KNIGHT, J. Doubts and dilemmas with double degree programs. International Journal of Educational Technology in Higher Education, v. 8, n. 2, p. 297-312, 2011.

KOSMODEMYANSKAYA, S.; NIZAMOV, I.; YARULLIN, I. Information and educational environment in the system of practices of the future teacher of chemistry. QUID:

Investigación, Ciencia y Tecnología, n. 1, p. 373-378, 2017.

MASLENNIKOVA, V. S.; TREGUBOVA, T. M.; KHUZIAKHMETOV, A. N. Theoretical and Methodological Problems of Developing Educational Innovations. Modern Journal of Language Teaching Methods, v. 7, n. 9/2, p. 63-71, 2017.

MASLENNIKOVA, V. S.; TREGUBOVA, T. M.; KHUZIAKHMETOV, A. N.; NASIBULLOV, R. R. The Problem of Innovative Development of The Modern Professional Education in Russia. The European Proceedings of Social \& Behavioral Sciences EpSBS, p. 508-517, 2017.

MUKHAMETZYANOVA, F.; TREGUBOVA, T.; KAMALEEVA, A. International experience as resource for improvement of multi-cultural teacher education in Russia. The European Proceedings of Social \& Behavioral Sciences EpSBS, p. 568-573, 2017.

NASIBULLOVA, G. R.; SALAKHOVA, R. I. Representation of beauty in English, Russian and Tatar linguocultures (on the material proverbs). Modern journal of language teaching methods, p. 45-49, 2016.

OLEYNIKOVA, O.N. Joint programmes of higher education as a factor of internationalization and increasing the efficiency of programmes. Bulletin of the Sholokhov Moscow State University for Humanities. Pedagogy and Psychology, n. 2, p. 69-79, 2014.

PORTUGAL. Joint Convention of the Council of Europe and UNESCO on recognition. Lisbon. Available: http://www.russianenic.ru/int/lisbon/index.html. Access: 10 dec. 2020. RUSSELL, A. W.; DOLNICAR, S.; AYOUB, M. Double degrees: double the trouble or twice the return? Higher Education, v. 55, n. 5, p. 575-591, 2008.

TAUCH, C.; RAUHVARGERS, A. Survey on master' degrees and joint degrees in Europe. 2002.

UNITED KINGDOM. Joint degree programme with the University of Nottingham Trent. 2011. Available: http://www.iee.unn.ru/files/2016/10/buklet-dlya-sajta.pdf. Access: 10 dec. 2020. 


\section{How to reference this article}

NIZAMOV, I. D.; NASIBULLOV, R. R.; OLEYNIKOVA, O. N.; GORYLEV, A. I. Some characteristics of the systematization of Joint International Programmes in Higher Education. Revista on line de Política e Gestão Educacional, Araraquara, v. 25, n. esp. 1, p. 567-576, mar. 2021. e-ISSN:1519-9029. DOI: https://doi.org/10.22633/rpge.v25iesp.1.14997

Submitted: 06/11/2020

Required revisions: 18/01/2021

Approved: $23 / 02 / 221$

Published: 01/03/2021 